\title{
Tris(1,10-phenanthroline)ruthenium(II)- and Tris(2,2'-bipyrazine)ruthenium(II)-Sensitized Photopolymerization of Acrylamide
}

\author{
Kaoru IwaI, Yoshiko Uesugi, Terumi Sakabe, Chiyo Hazama, \\ and Fukuo TAKEMURA ${ }^{\dagger}$ \\ Department of Chemistry, Faculty of Science, \\ Nara Women's University, Nara 630, Japan
}

(Received October 17, 1990)

\begin{abstract}
Photopolymerization of acrylamide (AA) sensitized by tris(1,10-phenanthroline)ruthenium(II) and tris $\left(2,2^{\prime}\right.$-bipyrazine)ruthenium(II) complexes $\left(\mathrm{Ru}(\mathrm{phen})_{3}^{2+}\right.$ and $\left.\mathrm{Ru}(\mathrm{bpz})_{3}^{2+}\right)$ was studied in aqueous solutions. AA was photopolymerized in the presence of both the sensitizer $\mathrm{Ru}(\mathrm{phen})_{3}^{2+}$ and an electron donor triethylamine (TEA). The photopolymerization of AA did not occur in the presence of the sensitizer $\mathrm{Ru}(\mathrm{bpz})_{3}^{2+}$ and TEA, but did in the coexistence of maleic acid as a comonomer. In these systems the $\mathrm{Ru}$ (II) complexes were not consumed during the polymerization. The mechanisms of photopolymerization for these systems are discussed.

KEY WORDS Tris(1,10-phenanthroline)ruthenium(II) Complex / Tris(2,2' bipyrazine)ruthenium(II) Complex / Photopolymerization / Acrylamide / Photosensitizer / Photoredox Reaction / Electron-Transfer Reaction /
\end{abstract}

In recent years, there have been widespread investigations of the photo-redox reactions of transition-metal complexes, especially ruthenium(II) complexes such as tris $\left(2,2^{\prime}\right.$-bipyridine)ruthenium(II) complex $\mathrm{Ru}(\mathrm{bpy})_{3}^{2+} \cdot{ }^{1-3}$ But, there are few studies of the ruthenium(II) complexes as a photo-redox initiator system for radical polymerization. ${ }^{4,5}$ In the previous paper $^{4}$ we reported the photopolymerization of acrylamide (AA) sensitized by $\mathrm{Ru}(\mathrm{bpy})_{3}^{2+}$ in aqueous solutions. The ruthenium(II) complex did not induce the photopolymerization of $\mathrm{AA}$ in the presence of an electron acceptor methylviologen, but did in the

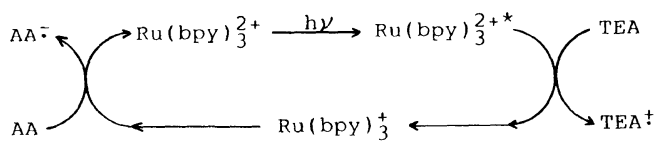

Scheme 1. presence of an electron donor triethylamine (TEA). In the aqueous Ru(bpy) ${ }_{3}^{2+}$-TEA-AA solution system, the photosensitizer $\mathrm{Ru}(\mathrm{bpy})_{3}^{2+}$ could be converted into $\mathrm{Ru}(\mathrm{bpy})_{3}^{+}$transiently, but was not consumed during the polymerization as shown in Scheme 1.

In the present paper the photopolymerization of AA sensitized by tris(1,10-phenanthroline)ruthenium(II) complex $\mathrm{Ru}(\mathrm{phen})_{3}^{2+}$, tris(2,2'-bipyrazine)ruthenium(II) complex $\mathrm{Ru}(\mathrm{bpz})_{3}^{2+}$, and tris(2,2'-bipyridine)osmium(II) complex Os(bpy) ${ }_{3}^{2+}$ has been studied in aqueous solutions. The polymerization mechanisms for these systems are discussed.

\section{EXPERIMENTAL}

\section{Materials \\ $\left[\mathrm{Ru}(\text { phen })_{3}\right] \mathrm{Cl}_{2} \quad\left(\varepsilon_{447}=171001 \mathrm{~mol}^{-1}\right.$ $\mathrm{cm}^{-1}$ ) was prepared according to the lit-}

\footnotetext{
† Present address: Kobe Gakuin University, Hyogo 651-21, Japan.
} 
erature. ${ }^{6}\left[\mathrm{Ru}(\mathrm{bpz})_{3}\right] \mathrm{Cl}_{2}\left(\varepsilon_{443}=150001 \mathrm{~mol}^{-1}\right.$ $\mathrm{cm}^{-1}$ ) was synthesized from $\mathrm{Ru}\left(\mathrm{Me}_{2} \mathrm{SO}\right)_{4} \mathrm{Cl}_{2}{ }^{7}$ and 2,2'-bipyrazine by the method cited in the literature. ${ }^{8}\left[\mathrm{Os}(\mathrm{bpy})_{3}\right] \mathrm{Cl}_{2}\left(\varepsilon_{480}=140001 \mathrm{~mol}^{-1}\right.$ $\mathrm{cm}^{-1}$ ) was prepared from $\mathrm{K}_{2} \mathrm{OsCl}_{6}{ }^{9}$ and 2,2'-bipyridine according to the method of Burstall. ${ }^{10}$ Acrylamide (AA) was recrystallized twice from benzene. Maleic acid (MA) was purified by recrystallization from acetone. Triethylamine (TEA, Nakarai Chemicals, GR) was used without further purification.

\section{Polymerization Procedure}

The photopolymerization was carried out similarly as described before. ${ }^{4}$ A freshly prepared sample solution was degassed by four freeze-pump-thaw cycles on a vacuum line and sealed into a quartz cell with a volume $4 \mathrm{ml}$, $1 \mathrm{~cm}$ in thickness. Photopolymerization was initiated by irradiation at $30^{\circ} \mathrm{C}$. As a stationary light source, an Ushio 500W Xenon short arc lamp was used together with a cutoff filter (Toshiba UV-39 or VY-44). The polymers were isolated by precipitation with methanol. The molecular weights of the polymers were measured in aqueous solutions by an Ostwald viscometer using the following equation, $[\eta]=6.8 \times 10^{-4} \bar{M}_{n}^{0.66} \cdot{ }^{11}$

\section{Measurements}

Absorption spectra were recorded on a Hitachi model 124 spectrophotometer and a Hitachi model U-3200 spectrophotometer, and transient absorption spectra were monitored by the same flash photolysis apparatus as described previously. ${ }^{4,12}$ Emission spectra were measured with a Hitachi model 850 fluorescence spectrophotometer. Redox potentials of TEA, AA, and MA were measured with a Hokuto HR-103A rotating electrode and a Hokuto-101 B dual potentiostat in $0.1 \mathrm{M}$ $\mathrm{Na}_{2} \mathrm{SO}_{4}$ aqueous solutions at room temperature. The light intensities were measured with a potassium tris(oxalato)ferrate(III) actinometer. ${ }^{13}$ The light intensity irradiated on the reaction cell through a cutoff filter VY-44 was
$2.3 \times 10^{-6} \mathrm{~mol} \mathrm{~s}^{-1} \mathrm{~cm}^{-2}$.

\section{RESULTS AND DISCUSSION}

\section{Initiation by Metal Complex-TEA System}

There was no ground state interaction among three components metal complex, TEA, and $\mathrm{AA}$ in an aqueous solution. The photopolymerization of AA was carried out by selective excitation of metal complex under the experimental conditions $([\mathrm{Ru}$ (II) complex $]=$ $5 \times 10^{-5} \mathrm{M}, \quad[\mathrm{Os}(\mathrm{II})$ complex $]=1 \times 10^{-4} \mathrm{M}$, $[\mathrm{TEA}]=0.5 \mathrm{M}$, and $[\mathrm{AA}]=2 \mathrm{M}$ ). The results of the polymerization experiments and the redox properties of the $\mathrm{Ru}(\mathrm{II})$ and $\mathrm{Os}(\mathrm{II})$ complexes are listed in Table I. In the $\mathrm{Ru}(\mathrm{phen})_{3}^{2+}$-sensitized system poly(AA) was obtained by irradiation and the $\mathrm{Ru}$ (II) complex was not consumed during the polymerization as well as in the case of the $\mathrm{Ru}(\mathrm{bpy})_{3}^{2+}$. sensitized system. However, AA was not photopolymerized in the systems containing $\mathrm{Ru}(\mathrm{bpz})_{3}^{2+}$ nor $\mathrm{Os}(\mathrm{bpy})_{3}^{2+}$ as a sensitizer. In the latter cases there was no spectral change of the Os(bpy $)_{3}^{2+}$ system by irradiation, but significant spectral change in the $\mathrm{Ru}(\mathrm{bpz})_{3}^{2+}$ system. Judging from the redox potentials of the excited metal complexes, $\mathrm{Ru}(\mathrm{bpz})_{3}^{2+*}$ is the

Table I. Photopolymerization in Ru(II) and Os(II) Complexes-Triethylamine-Acrylamide Systems $^{\mathrm{a}}$

\begin{tabular}{|c|c|c|c|c|}
\hline \multirow{3}{*}{$\begin{array}{c}\text { Metal } \\
\text { complex }\end{array}$} & \multirow{3}{*}{$\frac{\begin{array}{c}\text { Irradiation } \\
\text { time }\end{array}}{\text { min }}$} & \multirow{3}{*}{ Conv. } & \multicolumn{2}{|c|}{ Reduction potential } \\
\hline & & & $\mathrm{M}^{2+1+} /$ & $\mathrm{M}^{2+* /+}$ \\
\hline & & & V & V \\
\hline $\mathrm{Ru}(\mathrm{bpz})_{3}^{2+}$ & 30 & 0 & $-0.7^{\mathrm{c}}$ & $+1.5^{\mathrm{c}}$ \\
\hline $\mathrm{Ru}(\mathrm{bpy})_{3}^{2+}$ & 3 & 10.5 & -1.28 & +0.84 \\
\hline $\mathrm{Ru}(\mathrm{phen})_{3}^{2+}$ & 3 & 16.9 & -1.36 & +0.79 \\
\hline $\mathrm{Os}(\mathrm{bpy})_{3}^{2+}$ & 90 & 0 & -1.22 & +0.59 \\
\hline
\end{tabular}

$\left.{ }^{\mathrm{a}}\left[\mathrm{Ru}(\mathrm{bpz})_{3}^{2+}\right]=\left[\mathrm{Ru}(\mathrm{bpy})_{3}^{2+}\right]=\mathrm{Ru}(\mathrm{phen})_{3}^{2+}\right]=5 \times$ $10^{-5} \mathrm{M},\left[\mathrm{Os}(\mathrm{bpy})_{3}^{2+}\right]=1 \times 10^{-4} \mathrm{M},[\mathrm{TEA}]=0.5 \mathrm{M}$, and $[\mathrm{AA}]=2 \mathrm{M}$.

b Potentials are in $\mathrm{V} v s$. NHE from ref 14.

c Estimated from a positive shift of $c a .0 .6 \mathrm{~V}$ in the reduction potential between $\mathrm{Ru}(\mathrm{bpz})_{3}^{2+}$ and $\mathrm{Ru}-$ $(\text { bpy })_{3}^{2+}$. See ref 15 . 
strongest electron acceptor, but $\mathrm{Os}(\mathrm{bpy})_{3}^{2+*}$ is the weakest one in these four complexes. Thus Os(bpy $)_{3}^{2+*}$ could not be reduced by TEA. Further, $\mathrm{Ru}(\mathrm{phen})_{3}^{2+*}$ is a strong acceptor as well as $\mathrm{Ru}(\mathrm{bpy})_{3}^{2+*}$ that is reductively quenched by TEA. ${ }^{4,17}$ Although the reduction potential of $\mathrm{TEA}^{+}$estimated from the results of rotating electrode cyclic voltammetry is higher than those of both Ru-complexes as shown later in Figure 4, Ru(phen) ${ }_{3}^{2+*}$ might be expected to be reduced by TEA and to act as an effective sensitizer for the photopolymerization of AA. Therefore, we studied the $\mathrm{Ru}(\mathrm{phen})_{3}^{2+}$ - and $\mathrm{Ru}(\mathrm{bpz})_{3}^{2+}$-sensitized systems in detail.

\section{$R u(\text { phen })_{3}^{2+}-T E A-A A$ in $\mathrm{H}_{2} \mathrm{O}$ System}

The conversions of AA were dependent on its polymerization time, the $\mathrm{Ru}(\text { phen })_{3}^{2+}$ concentration, and the TEA concentration as seen in Table II. There appeared to be saturation phenomena in this system as well as in

Table II. Photopolymerization in $\mathrm{Ru}(\text { phen })_{3}^{2+}-$ TEA-AA System ${ }^{\mathrm{a}}$

\begin{tabular}{|c|c|c|c|}
\hline$\left[\mathrm{Ru}(\mathrm{phen})_{3}^{2+}\right]$ & [TEA] & $\begin{array}{c}\text { Polymn. } \\
\text { time }\end{array}$ & Conv. \\
\hline M & M & $\min$ & $\%$ \\
\hline $5 \times 10^{-5}$ & 0.5 & $0^{\mathbf{b}}$ & 0 \\
\hline $5 \times 10^{-5}$ & 0.5 & 3 & 16.9 \\
\hline $5 \times 10^{-5}$ & 0.5 & 4 & 22.4 \\
\hline $5 \times 10^{-5}$ & 0.5 & 7 & 31.2 \\
\hline $5 \times 10^{-5}$ & 0.5 & 10 & 34.2 \\
\hline 0 & 0.5 & 7 & 0 \\
\hline $5 \times 10^{-6}$ & 0.5 & 7 & 16.4 \\
\hline $1.5 \times 10^{-5}$ & 0.5 & 7 & 25.5 \\
\hline $5 \times 10^{-5}$ & 0.5 & 7 & 31.2 \\
\hline $7.5 \times 10^{-5}$ & 0.5 & 7 & 33.7 \\
\hline $5 \times 10^{-5}$ & 0 & 7 & 0 \\
\hline $5 \times 10^{-5}$ & 0.1 & 7 & 17.6 \\
\hline $5 \times 10^{-5}$ & 0.2 & 7 & 27.1 \\
\hline $5 \times 10^{-5}$ & 0.3 & 7 & 29.7 \\
\hline $5 \times 10^{-5}$ & 0.4 & 7 & 31.2 \\
\hline $5 \times 10^{-5}$ & 0.5 & 7 & 30.8 \\
\hline
\end{tabular}

a $[\mathrm{AA}]=2 \mathrm{M}$. b $12 \mathrm{~min}$ in the dark.
$\mathrm{Ru}(\mathrm{bpy})_{3}^{2+}{ }^{+}$-sensitized system. ${ }^{4}$ At all events AA was photopolymerized in the presence of both the sensitizer $\mathrm{Ru}(\mathrm{phen})_{3}^{2+}$ and the electron donor TEA. In this system no spectral change was observed before and after irradiation as described previously. In other words, Ru(phen $)_{3}^{2+}$ was not consumed during the polymerization, though the photopolymerization of AA occurred. Compared with $\mathrm{Ru}-$ $(\mathrm{bpy})_{3}^{2+}$-sensitized system, $\mathrm{Ru}(\mathrm{phen})_{3}^{2+}$-system is more effective as shown in Table III, in which the conversions and the molecular weights of the polymers are listed on the same concentrations and absorbances at $447 \mathrm{~nm}$ of these complexes. By assuming the biradical coupling terminations, the quantum yield for the initiation was estimated to be $2.8 \times 10^{-3}$.

The reaction mechanism of AA polymerization was studied with the aid of spectroscopy. The fact that the photopolymerization of AA did not occur in the presence of $\mathrm{Ru}(\mathrm{phen})_{3}^{2+}$ alone suggests that the polymerization was not initiated by $\mathrm{Ru}(\mathrm{phen})_{3}^{2+*}$ directly, but would be done by the photoredox products between $\mathrm{Ru}$ (phen) $)_{3}^{2+*}$ and TEA. The emission of $\mathrm{Ru}(\mathrm{phen})_{3}^{2+*}$ was reductively quenched by TEA. In the absence of AA the accumulation of $\mathrm{Ru}(\mathrm{phen})_{3}^{+}$, which had an absorption band located about $505 \mathrm{~nm}$, was observed in $N, N$ dimethylformamide (DMF) as shown in Figure 1. On the other hand, there was apparently no accumulation of the reduced ruthenium complex in the aqueous solution. This could be attributed to the reaction of $\mathrm{Ru}(\mathrm{phen})_{3}^{+}$with

Table III. Photopolymerization in $\mathrm{Ru}(\mathrm{phen})_{3}^{2+}$ and $\mathrm{Ru}(\mathrm{bpz})_{3}^{2+}$-TEA-AA systems ${ }^{\mathrm{a}}$

\begin{tabular}{|c|c|c|c|c|}
\hline \multirow{2}{*}{ Sensitizer } & Conc. & Absorb- & Conv. & \multirow{2}{*}{$\bar{M}_{n}$} \\
\hline & M & $447 \mathrm{~nm}$ & $\%$ & \\
\hline $\operatorname{Ru}(\text { phen })_{3}^{2+}$ & $5 \times 10^{-5}$ & 0.81 & $16.9^{b}$ & $4.8 \times 10^{4}$ \\
\hline $\mathrm{Ru}(\mathrm{bpy})_{3}^{2+}$ & $5 \times 10^{-5}$ & 0.79 & 10.5 & $5.2 \times 10^{4}$ \\
\hline $\mathrm{Ru}(\mathrm{bpy})_{3}^{2+}$ & $5.1 \times 10^{-5}$ & 0.81 & 11.6 & $5.0 \times 10^{4}$ \\
\hline
\end{tabular}

a $[$ TEA $]=0.5 \mathrm{M} ;[\mathrm{AA}]=2 \mathrm{M} ;$ polymn. time $=3 \mathrm{~min}$.

b Quantum yield for the initiation $=2.8 \times 10^{-3}$. 


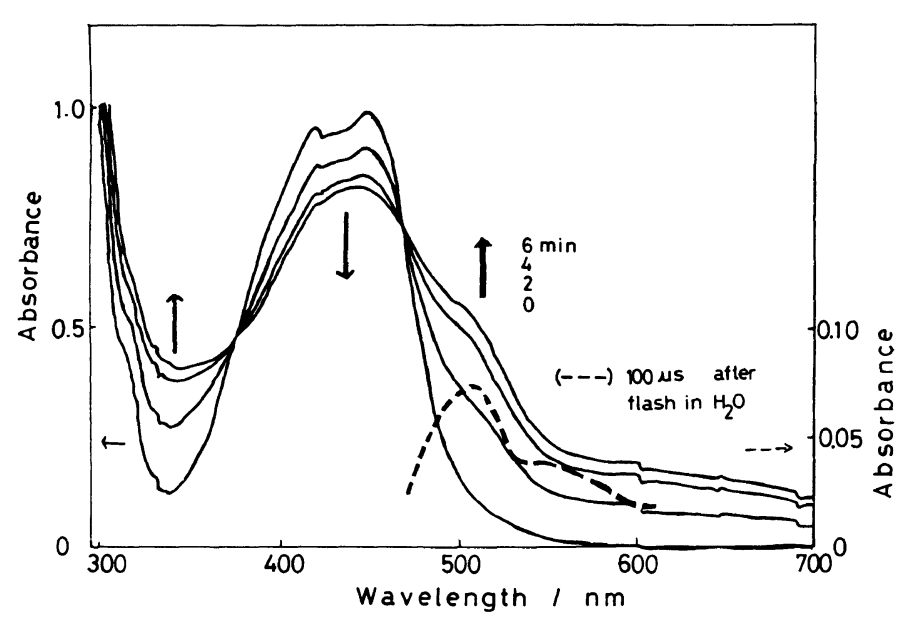

Figure 1. Absorption spectra of $\mathrm{Ru}(\mathrm{phen})_{3}^{2+}$-TEA system in DMF during visible light irradiation: $\left[\mathrm{Ru}(\mathrm{phen})_{3}^{2+}\right.$ ], $5 \times 10^{-5} \mathrm{M}$; [TEA], $0.5 \mathrm{M}$. Broken curve is transient absorption spectrum of an aqueous solution containing $\mathrm{Ru}(\mathrm{phen})_{3}^{2+}$ and TEA: [Ru(phen $)_{3}^{2+}$ ], $2.5 \times 10^{-5}$; [TEA], $0.5 \mathrm{M}$.
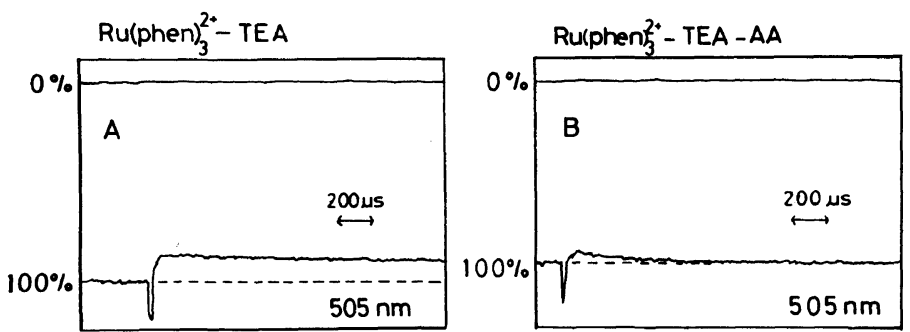

Figure 2. Decay curves of $\mathrm{Ru}(\text { phen })_{3}^{+}$absorption monitored at $505 \mathrm{~nm}$ : (A) $\left[\mathrm{Ru}(\mathrm{phen})_{3}^{2+}\right], 2.5 \times 10^{-5}$; [TEA], $0.5 \mathrm{M}$; (B) [Ru(phen) ${ }_{3}^{+}$], $2.5 \times 10^{-5}$; [TEA], 0.5 M; [AA], $1.2 \mathrm{M}$.

water as seen in other many ruthenium complexes, $\mathrm{RuL}_{3}^{+}$, where $\mathrm{L}$ denotes $2,2^{\prime}$ bipyridine derivatives. ${ }^{16}$ However, the $\mu$ second flash photolysis of the aqueous solution containing $\mathrm{Ru}(\mathrm{phen})_{3}^{2+}$ and TEA gave the transient absorption spectrum as shown in Figure 1. This absorption band must be that of $\mathrm{Ru}(\mathrm{phen})_{3}^{+}$. Figure 2 shows the decay profile of $\mathrm{Ru}(\mathrm{phen})_{3}^{+}$monitored at $505 \mathrm{~nm}$. The profile depended on the AA concentration and the decay was accelerated by the addition of AA. These facts suggest that AA can oxidize $\mathrm{Ru}$ (phen) ${ }_{3}^{+}$to $\mathrm{Ru}(\mathrm{phen})_{3}^{2+}$ with concomitant production of $\mathrm{AA}^{-}$. We conclude that the sensitizer $\mathrm{Ru}(\mathrm{phen})_{3}^{2+}$ is regenerated by the two successive electron-transfer processes as shown Scheme 2, and hence in this system $\mathrm{Ru}(\mathrm{phen})_{3}^{2+}$

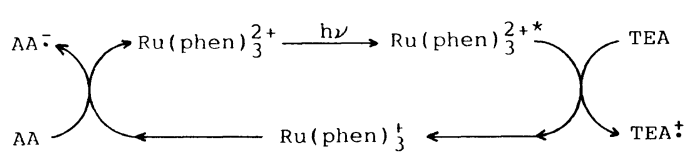

Scheme 2.

is the unconsumable photosensitizer.

With regard to the initiation of the polymerization, we could speculate as follows in the previous paper. ${ }^{4}$ The polymerization of AA could be initiated by the resulting products of the photoredox reactions such as $\mathrm{TEA}^{+}$, $\mathrm{AA}^{-}$, and their derivatives. In these species $\mathrm{CH}_{3} \dot{\mathrm{C}} \mathrm{HCONH}_{2}$ derived from $\mathrm{AA}^{-}$could contribute significantly to the initiation of polymerization. This speculation was confirmed experimentally by the results of the 
$\mathrm{Ru}(\mathrm{bpz})_{3}^{2+}$-sensitized system described in the following section.

\section{$R u(b p z)_{3}^{2+}-T E A-A A$ in $\mathrm{H}_{2} \mathrm{O}$ System}

In this system, a selective excited $\mathrm{Ru}(\mathrm{bpz})_{3}^{2+}$ was reduced by TEA, yielding $\mathrm{Ru}(\mathrm{bpz})_{3}^{+}$and $\mathrm{TEA}^{+}$and the accumulation of $\mathrm{Ru}(\mathrm{bpz})_{3}^{+}$was observed even in aqueous solutions as shown in Figure 3. This absorption spectrum of $\mathrm{Ru}(\mathrm{bpz})_{3}^{+}$was very similar to that of $\mathrm{Ru}(\mathrm{bpz})_{3}^{+}$ measured in ethanol. ${ }^{17} \mathrm{Ru}(\mathrm{bpz})_{3}^{+}$was stable in an aqueous solution and was oxidized by $\mathrm{O}_{2}$ to regenerate $\mathrm{Ru}(\mathrm{pbz})_{3}^{2+}$. Even though the AA monomer was added to the above redox system, no polymer was obtained by irradiation. The absorption spectrum of the polymerization system is very different from that before irradiation. These findings show that $\mathrm{TEA}^{+}$and its derivatives cannot initiate the polymerization of AA in aqueous solutions and $\mathrm{Ru}(\mathrm{bpz})_{3}^{+}$cannot reduce AA. This is consistent with the electrochemical data listed in Table $\mathrm{I}$, which shows that the reduction potential of $\mathrm{Ru}(\mathrm{bpz})_{3}^{2+}$ is shifted by $c a .0 .7 \mathrm{~V}$ more anodic compared with those of $\mathrm{Ru}(\mathrm{bpy})_{3}^{2+}$ and

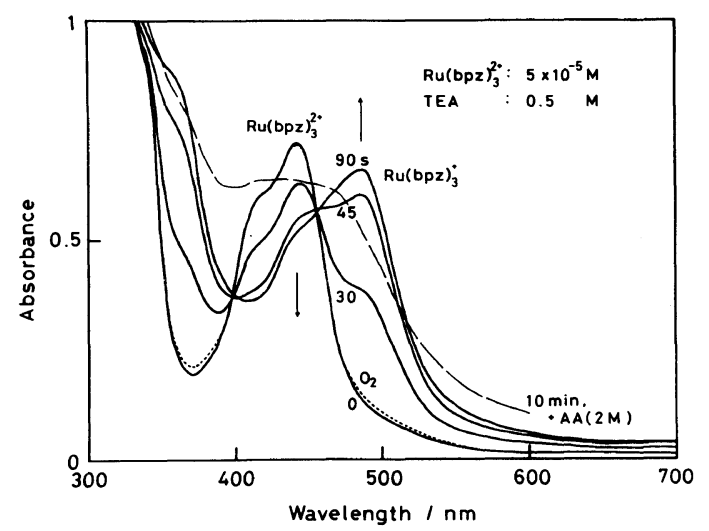

Figure 3. Absorption spectra of $\mathrm{Ru}(\mathrm{bpz})_{3}^{2+}-\mathrm{TEA}$ system in $\mathrm{H}_{2} \mathrm{O}$ during visible light irradiation: $\left[\mathrm{Ru}(\mathrm{pbz})_{3}^{2+}\right.$, $5 \times 10^{-5} \mathrm{M}$; [TEA], $0.5 \mathrm{M}$. Dotted curve, which almost overlaps with the initial spectrum of $\mathrm{Ru}(\mathrm{bpz})_{3}^{2+}$, represents an absorption spectrum on exposure to air after $90 \mathrm{~s}$ irradiation. Broken curve is a spectrum of an aqueous solution containing $\mathrm{Ru}(\mathrm{bpz})_{3}^{2+}$, TEA, and AA after $10 \mathrm{~min}$ irradiation: [Ru(bpz $)_{3}^{2+}$ ], $2.5 \times 10^{-5}$; [TEA], $0.5 \mathrm{M}$; [AA], $2 \mathrm{M}$.
$\mathrm{Ru}(\mathrm{phen})_{3}^{2+}$.

$R u(b p z)_{3}^{2+}-T E A-M A-A A$ in $\mathrm{H}_{2} \mathrm{O}$ System

AA was not photopolymerized in the presence of only this redox pair $\mathrm{Ru}(\mathrm{bpz})_{3}^{2+}$ and TEA, but was done in the presence of both the redox pair and the stronger electron acceptor maleic acid (MA). In the presence of MA there was no spectral change of the $R u(b p z)_{3}^{2+}$ sensitized system during the polymerization. The results of photopolymerization of AA were listed in Table IV. The polymer was not obtained by irradiation in the systems where anyone among $\mathrm{Ru}(\mathrm{bpz})_{3}^{2+}$, TEA, and MA was lacking. These results suggest that MA can oxidize $\mathrm{Ru}(\mathrm{bpz})_{3}^{+}$to $\mathrm{Ru}(\mathrm{bpz})_{3}^{2+}$ concomitantly with the production of $\mathrm{MA}^{-}$. Therefore, the basic reaction mechanism for this system is shown in Scheme 3.

The copolymerization of AA and MA could be initiated by the resulting product $\mathrm{MA}^{-}$and its derivatives such as $\mathrm{HOOC} \dot{C} \mathrm{HCH}_{2} \mathrm{COOH}$,

Table IV. Photopolymerization in the $\mathrm{Ru}(\mathrm{bpz})_{3}^{2+}-\mathrm{TEA}-\mathrm{MA}-\mathrm{AA}$ systems $^{\mathbf{a}}$

\begin{tabular}{|c|c|c|}
\hline \multirow{2}{*}{ System } & $\begin{array}{l}\text { Irradiation } \\
\text { time }\end{array}$ & \multirow{2}{*}{$\frac{\text { Conv. }}{\%}$} \\
\hline & $\min$ & \\
\hline $\mathrm{Ru}(\mathrm{bpz})_{3}^{2+}-\mathrm{TEA}-\mathrm{MA}-\mathrm{AA}$ & 30 & $22.6^{\mathrm{c}}$ \\
\hline $\mathrm{Ru}(\mathrm{bpz})_{3}^{2+}-\mathrm{TEA}-\mathrm{MA}-\mathrm{AA}$ & $0^{\mathrm{b}}$ & 2.3 \\
\hline $\mathrm{Ru}(\mathrm{bpz})_{3}^{2+}-\mathrm{TEA}-\quad-\mathrm{AA}$ & 30 & 0 \\
\hline $\mathrm{Ru}(\mathrm{bpz})_{3}^{2+}-\mathrm{TEA}-\mathrm{MA}-$ & 30 & 0 \\
\hline $\mathrm{Ru}(\mathrm{bpz})_{3}^{2+}-\quad-\mathrm{MA}-\mathrm{AA}$ & 30 & 0 \\
\hline -TEA-MA-AA & 30 & Trace \\
\hline -TEA-MA-AA & $0^{\mathrm{b}}$ & Trace \\
\hline \multicolumn{3}{|l|}{$\begin{array}{l}\text { a }\left[\mathrm{Ru}(\mathrm{bpz})_{3}^{2+}\right]=5 \times 10 \\
{[\mathrm{AA}]=1 \mathrm{M} .} \\
\text { b. } 35 \mathrm{~min} \text { in the dark. } \\
\text { c } \bar{M}_{n}=7.7 \times 10^{6} .\end{array}$} \\
\hline$\rightarrow \mathrm{Ru}(\mathrm{bpz}) 3_{3}^{2+}$ & $u(b p z) 3_{3}^{2+*}$ & \\
\hline
\end{tabular}

Scheme 3. 


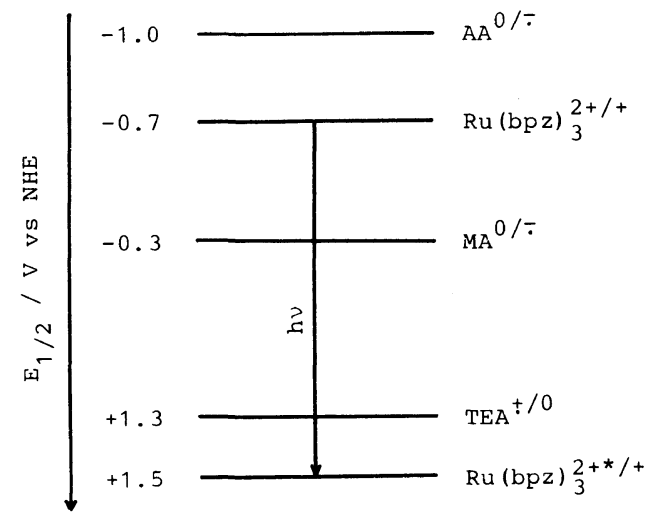

Figure 4. Redox potential diagram.

since $\mathrm{TEA}^{+}$and its derivatives cannot initiate the polymerization of AA as described before. The copolymer obtained in this experiment is of very large molecular weight $\left(7.7 \times 10^{6}\right)$ and composed of about $93 \%$ AA, which is estimated from $Q-e$ values $^{18}$ of these monomers.

This is supported by the redox potential data summarized in Figure 4. From Figure 4, the excited complex $\mathrm{Ru}(\mathrm{bpz})_{3}^{2+*}$ is expected to act as an electron acceptor from TEA, but not to do as an electron donor to MA. $\mathrm{Ru}(\mathrm{bpz})_{3}^{+}$ produced by the redox reaction between $\mathrm{Ru}(\mathrm{bpz})_{3}^{2+*}$ and TEA can be expected to act as an electron donor to MA, leading to the regeneration of $\mathrm{Ru}(\mathrm{bpz})_{3}^{2+}$, but not to AA. Moreover, TEA + may be not concerned in the termination and chain transfer reactions, since the rate of polymerization sensitized by $\mathrm{Ru}(\mathrm{phen})_{3}^{2+}$ is considerably high and the molecular weight of the polymer obtained in the $\mathrm{Ru}(\mathrm{bpz})_{3}^{2+}$-system is extremely large. Consequently, we conclude that $\mathrm{Ru}(\mathrm{bpz})_{3}^{2+}$ is the unconsumable photosensitizer and is regenerated by the two successive electrontransfer processes as shown in Scheme 3.

\section{CONCLUDING REMARKS}

In the $\mathrm{Ru}(\mathrm{phen})_{3}^{2+}-\mathrm{TEA}-\mathrm{AA}$ system, $\mathrm{AA}$ is photopolymerized and the sensitizer
$\mathrm{Ru}(\mathrm{phen})_{3}^{2+}$ is regenerated by the two successive electron-transfer processes, that is, $\mathrm{Ru}$ $(\text { phen })_{3}^{2+}$ is the unconsumable photosensitizer. In the $\mathrm{Ru}(\mathrm{bpz})_{3}^{2+}-\mathrm{TEA}-\mathrm{AA}$ system, on the other hand, no polymer is obtained. By use of the stronger electron-accepting monomer MA as a comonomer, the MA-AA copolymer is obtained and $\mathrm{Ru}(\mathrm{bpz})_{3}^{2+}$ is regenerated completely, that is, $\mathrm{Ru}(\mathrm{bpz})_{3}^{2+}$ is the unconsumable photosensitizer, too.

In these polymerization systems, the two ruthenium(II) complexes could be converted to the corresponding ruthenium(I) complexes transiently, but was not consumed. These systems as well as the $\mathrm{Ru}(\mathrm{bpy})_{3}^{2+}$-sensitized system described before could be one type of ideal photosensitized polymerization systems.

\section{REFERENCES}

1. D. G. Whitten, Acc. Chem. Res., 13, 83 (1980).

2. K. R. Barqawi, A. Llobet, and T. J. Meyer, J. Am. Chem. Soc., 110, 7751 (1988).

3. T. J. Meyer, Acc. Chem. Res., 22, 163 (1989).

4. K. Iwai, M. Uesugi, and F. Takemura, Polym. J., 17, 1005 (1985).

5. C. K. Gratzel, M. Jirousek, and M. Gratzel, Langmuir, 2, 292 (1986).

6. J. N. Braddock and T. J. Meyer, J. Am. Chem. Soc., 95, 3158 (1973).

7. I. P. Evans, A. Spencer, and G. Wilkinson, J. Chem. Soc., Dalton Trans., 204 (1973).

8. R. J. Crutchley and A. B. P. Lever, Inorg. Chem., 21, 2276 (1982).

9. F. P. Dwyer and J. W. Hogarth, "Inorganic Syntheses," Vol. V, McGraw-Hill, 1957, p 206.

10. F. H. Burstall, F. P. Dwyer, and E. C. Gyarfas, J. Chem. Soc., 953 (1950).

11. J. Brandrup and E. H. Immergut, Ed., "Polymer Handbook," John-Wiley \& Sons, New York, N.Y., 1975, IV-9.

12. F. Takemura and K. Sakaguti, Nippon Kagaku Kaishi, 1470 (1976).

13. S. L. Murov, "Handbook of Photochemistry," Marcel Dekker, New York, N.Y., 1973, p 119.

14. N. Sutin and C. Creus, Adv. Chem. Ser., 168, 1 (1978).

15. D. P. Rillema, G. Allen, T. J. Meyer, and D. Conrad, Inorg. Chem., 22, 1617 (1983).

16. P. J. DeLaive, J. T. Lee, H. W. Sprintschnik, H. Abruna, T. J. Meyer, and D. G. Whitten, J. Am. Chem. Soc., 99, 7094 (1977). 


\section{Photopolymerization of AA Sensitized by $\mathrm{Ru}(\mathrm{II})$ Complexes}

17. R. J. Crutchley and A. B. P. Lever, J. Am. Chem. Soc., 102, 7128 (1980).

18. J. Brandrup and E. H. Immergut, Ed., "Polymer
Handbook," John-Wiley \& Sons, New York, N.Y., 1975, II-387. 